\title{
ATOR SINCERO E ATOR CÍNICO: a análise das interações comunicacionais no contexto organizacional a partir da perspectiva dramatúrgica de Erving Goffman
}

\author{
Dôuglas Aparecido Ferreira ${ }^{1}$
}

Resumo: Este artigo se propõe a realizar uma reflexão teórica sobre o Interacionismo Simbólico e resgata suas principais ideias no intuito de se compreender as complexas relações comunicacionais que se dão no contexto das organizações, principalmente aquelas que envolvem trabalhadores subordinados e subordinadores. Para tanto, foram utilizados os conceitos de ator sincero e ator cínico de Erving Goffman (2013) como operadores analíticos para se entender as estratégias de comunicação e as representações de papéis sociais que marcam um jornal interno.

Palavras-chave: Comunicação no contexto das organizações; ator sincero; ator cínico, estratégias de interação.

\begin{abstract}
This article proposes to make a theoretical reflection about Symbolic Interactionism and rescues its main ideas to understand the complex communication relations that happen in the context of organizations, especially those involving subordinate and subordinate workers. For that, the concepts of sincere actor and cynical actor of Erving Goffman (2013) were used as analytical operators to understand the communication strategies and representations of social roles that mark a house organ.
\end{abstract}

Keywords: Communication in the context of organizations; sincere actor; cynical actor, interaction strategies.

\section{Introdução}

Entre os mais recorrentes questionamentos que instigam pesquisas sobre os processos comunicacionais no ambiente interno das organizações, os conflitos de interesses entre os atores sociais, principalmente trabalhadores subordinados e subordinadores ${ }^{2}$, são alguns dos mais inquietantes problemas investigativos, suscitando inesgotáveis tentativas de se entender essas complexas relações.

\footnotetext{
${ }^{1}$ Professor da Universidade do Estado de Minas Gerais. Membro do Núcleo de Educação a Distância da Universidade Federal de São João Del-Rey. Coordenador da Agência Experimental do Curso de Publicidade e Propaganda da UEMG - Unidade Divinópolis. Doutorando em Comunicação Social na Universidade Federal de Minas Gerais. Mestre em Comunicação Social - Interações Midiáticas pela Pontifícia Universidade Católica de Minas Gerais (2015), com período sanduíche na Ural Federal University (UrFU - Ecaterimburgo - Rússia). Membro pesquisador do Grupo DIARLOG - Comunicação no Contexto Organizacional: aspectos teóricoconceituais (PUC-Minas). Especialista em Gestão de Marcas e Identidade Corporativa pela Pontifícia Universidade Católica de Minas Gerais (2013) e bacharel em Comunicação Social (Gestão da Comunicação Integrada) - Habilitado em Publicidade e Propaganda pela Pontifícia Universidade Católica de Minas Gerais (2009). Vencedor do Prêmio ABRAPCORP de Teses e Dissertações em 2016.

${ }^{2}$ Os termos subordinados e subordinadores serão utilizados neste artigo por acreditar-se que eles representam melhor a complexidade das relações de poder deste estudo, que não necessariamente se dão em uma circunstância empregatícia (empregado e empregador), uma vez que estão inseridas em uma situação hierárquica mais política.
} 
No entanto, parte significativa da produção acadêmica sobre essa temática, geralmente fundamentada em uma perspectiva funcionalista e prescritiva, privilegia o desempenho do profissional de comunicação como o "harmonizador" desses conflitos, não refletindo sobre as tensões contextuais que perpassam o ambiente organizacional como a histórica relação de poder e as representações de papéis.

Por se tratar de um trabalho sobre a representação social, aqui utilizada no sentido de performance dramatúrgica proposta por Erving Goffman (2013), entende-se que o termo ator social seja o mais potente para qualificar os indivíduos como agenciadores das impressões que causam em suas plateias. Segundo D’Almeida (2015), os atores dispõem de uma margem de liberdade que utilizam estrategicamente em suas interações, mesmo em situações em que o sistema ao qual eles estão inseridos opera fortemente suas técnicas de poder. Essa visão permite entender as organizações como um espaço onde há um constante jogo de exigências e negociações, mas também uma emancipação do ator em escolher o papel que representará em cada situação.

Cabe destacar que são por meio dos processos comunicativos que os atores constroem e disputam sentidos com outros atores (BALDISSERA, 2009) e, consequentemente, percebem as regras que marcam a situação interacional. A partir disso, entende-se que a comunicação é um processo instaurador de espaços de negociação com o potencial de promover encontros articulados por diálogos e disputas (OLIVEIRA; PAULA, 2005) que exigem dos atores sociais neles envolvidos uma maior atenção aos aspectos que vão além do enunciado. Afinal, o estar em relação demanda dos atores uma pré-leitura da situação para facilitar a escolha da representação encenada, e essa seleção é fundamental para a garantia do desenrolar da interação e para a prática da melhor estratégia de relacionamento (GOFFMAN, 2013).

O presente estudo tem por objetivo entender as representações dos atores sociais no ambiente organizacional e analisar quais as estratégias de interação eles recorrem para garantir suas interações, tendo em vista que o contexto onde atuam está sob o regimento de regras de poder compartilhadas entre os grupos subordinadores - a gestão - e os subordinados - os empregados.

Para tanto, serão investigadas as representações de papéis identificadas no conteúdo do jornal Piãoneiro/Roda Livre, um informativo mensal, criado em 2006, por meio da iniciativa espontânea de um empregado que tinha a intenção de fazer circular informações de caráter 
informal entre seus pares. A expectativa é de que as discussões aqui levantadas possam contribuir para o aprofundamento dos estudos da comunicação no contexto das organizações, a partir da compreensão do jogo de interesses e das performances de representação que envolvem os atores sociais. Parte-se do pressuposto que, ao identificar as representações de papéis presentes no jornal, seja possível a apreensão das estratégias orientadas pela ordem do poder instalada nas organizações.

\section{Um breve resgaste dos conceitos basilares do Interacionismo Simbólico}

O Interacionismo Simbólico e suas releituras feitas principalmente por Vera França (2007; 2008) têm proporcionado contribuições significativas para o entendimento dos processos comunicacionais. Essa perspectiva tem se mostrado também potente nas empreitadas investigativas oriundas do subcampo da comunicação organizacional (LIMA, 2008), uma vez que essa corrente de pensamento contribui para a crença de que o significado é resultante das indeterminadas interpretações conscientes provocadas durante as interações sociais tangenciadas pelo contexto onde ocorrem.

Ainda sobre as contribuições teórico-metodológicas, Ferin (2002) lembra que o Interacionismo Simbólico reforça a ideia da inexistência de ações humanas separadas da interação. Segundo a autora, isso se deve pelo fato do mundo ser composto de objetos (físicos, coisas; sociais, pessoas; abstratos, ideias) que adquirem significado somente através da interação simbólica. Neste caso, o conceito de interação se torna ainda mais potente quando designa uma situação em que não apenas os atores interagem, mas também definem o quadro da ação e os sentidos produzidos. Interagir é se colocar em relação e, consequentemente, se entremear em um complexo conjunto de expectativas recíprocas (FRANÇA; SIMÕES, 2014).

A interação é um evento que modifica os atores envolvidos no processo. Durante e após um processo interacional, o ator se vê afetado pela relação na qual ele também afetou (ALMEIDA; LIMA, 2010). O Interacionismo Simbólico trouxe um novo olhar para as relações humanas, revelando um processo que não se resume a uma ação unidirecional, previsível e controlável; pelo contrário, busca destacar uma trama de possibilidades resultantes de um encontro interacional. 
É nesta perspectiva que a abordagem interacional da comunicação avança conceitualmente quando comparada ao modelo clássico da comunicação emissor/receptor, pautada na ideia dos sentidos transmitidos de forma determinística.

Daltoé (2004) aponta que a grande implicação metodológica do Interacionismo Simbólico é a preocupação com a dimensão empírica, a rejeição aos modelos de comunicação prontos, acabados, e a necessidade de se avaliar os processos interpretativos pelos quais os significados sociais se constroem, através dos atores sociais que são agentes e, portanto, ativos no processo comunicativo. Utilizar o viés interacional para se entender um fenômeno da comunicação é postular o fato de que ele acontece concretamente dentro de um contexto temporal e espacial, permeado de traços de influências de outros contextos e agenciado por interlocutores que carregam consigo estratégias, desejos, necessidades, valores, expectativas, repertórios e diversos papéis sociais. Assim sendo, pode-se entender que a visada interacional da comunicação é também uma tentativa de valorizar os efeitos da circulação nos intercâmbios entre os atores sociais.

De fato, a perspectiva interacional não inaugura um novo modelo de comunicação, os elementos básicos continuam ali: emissor, receptor, meio e mensagem, mas ao invés de estarem relacionados de forma linear, eles são entendidos como articulares multiafetadores e multiafetados que interferem significativamente em todo o processo comunicativo.

A reflexão, até aqui feita, coloca as organizações como ambientes privilegiados para se estudar a comunicação a partir de um viés interacional, afinal, elas (as organizações) são espaços de intensas disputas de interesses e um constante jogo de estratégias (re)construídas o tempo todo pela/através da comunicação. Nesses contextos, a comunicação "não é um ato de atribuição de sentidos, que se realizaria automaticamente entre produtor e receptor. Mas, pelo contrário, um jogo no qual a questão dos sentidos se engendra em meio às disputas de estratégias e de operações de enunciação." (FAUSTO NETO, 2008, p. 54). O fato de estarem inseridas em âmbitos sociais dinâmicos e não serem atividades encasteladas, autossuficientes em si mesmas, faz com que as organizações sejam atravessadas por estratégias de relacionamento originárias de diversos grupos internos e externos, criando uma situação de indeterminismos e complexidades. Essas estratégias se (re)constroem o tempo todo e são através dos processos de comunicação que elas se potencializam, "uma vez que a comunicação propicia espaços de interação entre organização e atores sociais." (OLIVEIRA; PAULA, 2005, p. 19). E é através dessa possibilidade de a comunicação criar espaços comuns 
de interação que as figuras do emissor e receptor perdem suas funções de emitir e receber mensagens e se transformam em interlocutores. Quando se considera que as partes envolvidas são interlocutores, pressupõe-se uma situação de diálogo e negociação e, portanto, o espaço comum é o local onde a argumentação, as opiniões, as propostas e as divergências se dão (OLIVEIRA; PAULA, 2005).

\section{Goffman e a perspectiva interacional}

Embora Goffman recusasse a ser enquadrado em escolas sociológicas ${ }^{3}$, os estudos dedicados ao Interacionismo Simbólico insistem em citá-lo entre seus autores expoentes. $\mathrm{Na}$ verdade, Goffman foi aluno de pós-graduação na Universidade de Chicago, entre as décadas de 1930 e 1950, quando os principais textos de George H. Mead, uma das principais referências dessa perspectiva teórica, foram publicados. Isso fez com que Goffman tivesse contato direto com a efervescência crítica do Interacionismo Simbólico, o que certamente influenciou toda a sua obra e visão de mundo (NUNES, 2005).

Por acreditar no esforço dos atores sociais em construir cenicamente uma imagem que lhes seja favorável, considera-se que as premissas de Goffman se tornam também relevantes para o entendimento das complexas relações de poder que se dão no contexto organizacional, afinal "o ponto central da análise de Goffman é como o indivíduo apresenta a si mesmo nas situações do dia-a-dia, buscando o controle sobre a impressão que causa.” (WOOD JR., 2001, p. 47).

As abordagens goffmanianas se aproximam dos estudos do Interacionismo Simbólico ao reconhecerem que as circunstâncias das interações são fundamentais para que os indivíduos selecionem o papel mais apropriado a ser desempenhado (NUNES, 2005). Nesse sentindo, ao afirmar: "não, então, homens e seus momentos. Em vez disso, momentos e seus homens", Goffman (2011, p. 11) deixa claro seu destaque ao termo "momentos" em detrimento à palavra "homens", reforçando sua preocupação com a construção do sujeito a partir do contexto em que ele atua e não o contrário.

\footnotetext{
${ }^{3}$ Em entrevista concedida à Josef Verhoeven em 13 de Junho de 1980, Goffman declarou que: "Eu suponho que sou o que você chama um interacionista simbólico tanto como qualquer outra pessoa. Mas sou também um funcionalista estrutural no sentido tradicional; assim, se não posso responder a essa questão, é porque não acredito que o rótulo cubra, de facto, alguma coisa. E o que eu fiz até há alguns anos, antes de estar interessado na Sociolinguística, foi uma versão de Etnografia Urbana com Psicologia Social Meadiana." (GOFFMAN apud SERRA, 2007, p. 135).
} 
Para Goffman (2013), toda interação está inscrita em uma conjuntura situacional e esta última acaba sendo ordenadora dos demais elementos que compõe a cena: as expectativas dos atores e da plateia e os sentidos ali construídos e disputados. Contextualizando esses pressupostos, pode-se dizer que o ambiente organizacional, assim como qualquer outro, exige de seus atores sociais uma leitura das situações nele ocorridas no intuito de facilitar a escolha do papel a ser representado.

Os preceitos elementares da obra de Goffman apresentados nesta seção são fundamentais para a proposta deste trabalho, isto é, para o entendimento dos processos de comunicação no contexto das organizações a partir das adaptações e dos jogos de ajustes exigidos pela relação entre o ator e a plateia. Depois das discussões até aqui resgatadas considera-se a interferência de pelo menos três variáveis nas interações comunicacionais: o contexto situacional, a representação de papéis e a disputa pelo poder.

\section{Marcas das estratégias do ator sincero e do ator cínico no jornal Piãoneiro/Roda Livre}

O jornal Piãoneiro/Roda Livre foi um produto de comunicação de curta duração desenvolvido por um empregado do setor de logística para ser uma publicação não-oficial ${ }^{4}$ de uma empresa de pequeno porte do interior de Minas Gerais atuante no ramo de distribuição de peças para o mercado de bicicletas. O informativo circulou de março a novembro de 2006, período em que a organização passava por uma fase de transformação no modelo administrativo: de uma gestão familiar para a implantação de uma nova estrutura dos setores, encabeçados por gerentes recém contratados vindos da capital.

Durante esta fase, o proprietário da empresa era uma figura de poder influente entre os empregados. Contudo, apesar de sua presença física, ele já não atuava diretamente nas decisões, que foram sendo aos poucos assumidas pelos novos gestores.

O jornal analisado teve uma participação significativa que alterou a relação entre dois grupos que constituíam a organização, a saber, o "da parte de cima” e o "da parte de baixo". A arquitetura da empresa delimitava esses dois grupos: a parte de baixo era composta por empregados com cargos de subordinação e a parte de cima apresentava atores organizacionais

\footnotetext{
${ }^{4}$ A partir dos estudos de Baldissera, entende-se como comunicação não-oficial aquela que não é planejada pela organização. Para mais sobre o assunto ver BALDISSERA, Rudimar. Comunicação Organizacional na perspectiva da complexidade. Organicom (USP), v. 10-11, p. 115-120, 2009.
} 
dos dois grupos: subordinados (televendas e técnicos administrativos; empregados com grau menos acentuado de subordinação) e subordinadores (gerentes e o proprietário).

A primeira edição recebeu o nome de Piãoneiro e foi redigida à mão pelo empregado criador da proposta. O título do jornal aponta alguns sentidos interpretativos como: o jornal feito pelos peões ${ }^{5}$, o pioneirismo da iniciativa e o nome de uma das peças da bicicleta, remetendo assim à atividade da empresa.

Esse jornal era lido às escondidas pelos empregados da parte de baixo e para isso utilizavam o recurso de escondê-lo embaixo das pranchetas para que o grupo da parte de cima não tomasse conhecimento de sua existência.

O veículo é marcado pela informalidade. A temática do jornal se mostra como uma tentativa de publicar assuntos do âmbito do cotidiano dos empregados da parte de baixo, utilizando-se de recursos linguísticos e visuais como gracejos, anedotas, trocadilhos, sátiras e ironias para circular informações comuns à rádio peão. As matérias são escritas sem um compromisso com as regras dos manuais de redação.

Alheio à vontade de seu criador, o jornal foi parar na parte de cima da empresa, tornando-o de conhecimento do proprietário. Na tentativa de controlar as futuras edições, o dono, na ocasião, chamou o criador do jornal para conversar e estabeleceu um acordo com ele de que o jornal poderia continuar circulando, desde que houvesse um cuidado com o conteúdo, de modo que ele não causasse problemas de convivência, ou ainda, processos judiciais por difamação, uma vez que o veículo relatava episódios engraçados envolvendo os empregados.

Após esse fato, o jornal se transformou no veículo de comunicação oficial da empresa, e passou por algumas mudanças. O nome é alterado para Roda Livre, já que não pertencia somente aos peões. A produção passa a ser feita em um computador e percebe-se a inclusão de matérias questionando as condições de trabalho dos setores da parte de baixo, isso transforma o informativo também em um espaço para levantar causas trabalhistas.

A terceira edição marca o início da última fase do jornal. A partir dela, a equipe do setor de marketing começa a atuar ativamente nele, tanto na produção de conteúdo, quanto na diagramação. Percebe-se, neste período, um aumento considerável na quantidade de assuntos de caráter institucional dividindo espaço com as matérias de estilo informal e as de

\footnotetext{
${ }^{5}$ Nome pejorativo que os empregados se referiam a si próprios.
} 
reivindicações, cada vez menos presentes. Esse conflito de interesses entre subordinados e subordinadores dura até o fim da publicação, na sua oitava edição.

Além da análise das estratégias de atuação marcadas no conteúdo do jornal para o entendimento dos processos comunicativos no contexto organizacional, percebeu-se também a necessidade de resgatar a situação em que a publicação se deu. Para tanto, foram realizadas entrevistas em profundidade, através de questionários semiestruturados, com os principais atores identificados na formulação do jornal: o idealizador, o antigo gerente de marketing e seu estagiário, um empregado que exercia funções na "parte de cima", um empregado da "parte de baixo" e o então gerente de recursos humanos.

O fato dos atores sociais discretamente solicitarem que suas plateias - seus observadores - levem a sério a impressão representada perante ela (GOFFMAN, 2013), explica a preocupação dos empregados participantes do Jornal Piãoneiro/Roda Livre em ajustar suas performances de acordo com aquilo que eles julgavam ser aceitável pela gestão da empresa. "Era muita coisa que, às vezes, dava comentário. As pessoas podiam achar... 'Lidiane estava numa alegria no brinde...', talvez hoje no RH isso não dava.” (EPC, grifo nosso $)^{6}$. No depoimento citado, o entrevistado faz referência a uma nota da sétima edição do jornal: "Lidiane estava uma alegria só, era brindes para lá, brindes para cá. O que será que tanto brindava?" (RODA LIVRE, 2006g, p. 2). EPC sugere que a plateia durante o período de circulação do jornal era diferente da atual, uma vez que, como já relatado, a empresa ainda estava se profissionalizando e não constava com um setor de Recursos Humanos. Ou seja, esse tipo de declaração era cabível devido a informalidade do informativo, consequência do meio ao qual circulava e do tipo de relação compartilhada entre os envolvidos. Todavia, hoje, a mesma informação, segundo o entrevistado, não seria tolerada pelo setor de Recursos Humanos, talvez por tratar do consumo de bebidas alcoólicas e do comportamento excedido

\footnotetext{
${ }^{6}$ Para preservar a identidade dos entrevistados, esta pesquisa não publica os seus nomes, todavia, para demonstrar as diferentes perspectivas de acordo com o grupo ao qual pertenciam (subordinador e subordinado), optou-se por identifica-los por setores ou papel de atuação em relação ao jornal, às vezes grafados com o termo completo e outras com as iniciais: Criador do jornal (CJ), Gerente de marketing (GM), Estagiário de marketing (EM), Gerente de Recursos Humanos (GRH), Empregado da parte de baixo (EPB) e Empregado da parte de cima (EPC). Acredita-se que assim ficará mais perceptível as nuances dos discursos a partir dos diferentes interesses que compõem a empresa. Além disso, apesar do grupo de entrevistados ter sido composto por homens e mulheres, para evitar identificações e impossibilitar análises das diferenças a partir dos gêneros, optou-se por referir-se a eles segundo a norma culta da língua portuguesa, ou seja, padronizou-se os substantivos e adjetivos no gênero masculino. Por fim, quando as falas se referem a outros atores organizacionais não entrevistados nesta pesquisa, será utilizado um pseudo-nome acrescido de uma informação sobre sua posição hierárquica, quando necessário.
} 
de Lidiane. Entende-se, portanto, que durante uma representação, de modo geral, o ator se apresenta para o benefício e a crença de sua plateia.

Quanto a esses ajustes dos atores sociais para se adequarem às expectativas de suas plateias, Goffman (2013) defende a existência de dois extremos. Num deles se encontra o ator sincero, inteiramente compenetrado em seu desempenho e convencido de que a impressão da realidade encenada por ele é verdadeira. Essa crença do ator sincero na realidade representada é também compartilhada pela plateia e isso cria uma situação onde não há dúvidas quanto a veracidade das coisas. Isso pode ser percebido quando o EPC afirma já ter participado da coluna de entrevistas em dois jornais distintos da empresa, o Piãoneiro/ Roda Livre, já apresentado, e o Mais Comunicação, veículo atual planejado e executado pelos setores de marketing e recursos humanos. Em entrevista, ele sugere que sua atuação no primeiro jornal foi mais sincera quando comparada ao segundo.

Tudo que eu falei, ou tudo que eu escrevi respondendo, foi descrito na forma fiel. Não teve vírgula, maquiagem, nem nada assim. Hoje, é uma narração, e antes não, era a resposta certinha. Hoje o jornal da empresa fala assim: 'para fulano de tal, foi muito importante, é muito importante trabalhar na empresa, porque isso somou a seus conhecimentos', ... é uma narração! Há pouco tempo, eu fui entrevistada, mas eu achei que o texto que escreveram foi uma narração do que eu falei. É uma narrativa do que você falou, tem muita palavra ali que você não falou. Nem tive ânimo de ler a minha entrevista até o final. (EPC, grifo nosso).

Havia uma crença dos empregados no primeiro jornal de estarem participando de um espaço da verdade e da lisura. Entretanto, isso não significa que as entrevistas publicadas no Piãoneiro/Roda Livre fossem pautadas na plena liberdade de expressão de ideias do empregado. Cabe lembrar que as regras de poder não desaparecem em situações de atuações sinceras. $\mathrm{O}$ fenômeno que acontece é outro. $\mathrm{O}$ ator sincero continua convencido das disputas envolvidas no contexto, mas isso não o impede de acreditar em sua atuação como uma performance insuspeita para ele e sua plateia. A esta última, cabe compartilhar e aceitar a representação do ator. Convicta do espetáculo encenado, a plateia não tem dúvidas do que se apresenta a ela.

$\mathrm{O}$ ator sincero confia arduamente em sua atuação ao ponto de depositar nela uma credibilidade inquestionável. É como se sua representação fosse inabalável porque ela retrata o que é verdade para ele, levando-o a acreditar na impossibilidade de questionamentos por parte da plateia. A perspectiva da atuação sincera foi usada por CJ para explicar a charge a seguir: 


\title{
Figura 1: Charge "Expedição em dia de chuva de vento"
}

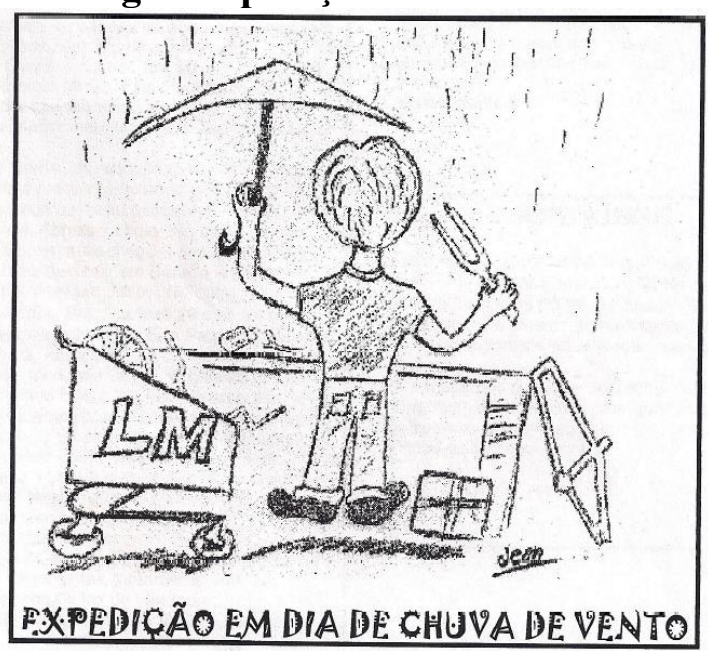

Fonte: Jornal Roda Livre - $3^{\text {a }}$ edição

Segundo CJ, o desenho foi solicitado para retratar uma situação recorrente na empresa: o teto do galpão não suportava chuvas com ventos e, consequentemente, molhava os trabalhadores.

\begin{abstract}
A gente queria uma ilustração engraçada porque estava desse jeito, estava quase precisando trabalhar como está no desenho. Eles [membros da gestão] resolveram o problema pouco depois. Rapidinho eles deram um jeito de chamar o pessoal lá e colocou mais telhas e consertou. Aí, acabou com esse problema. Mas o Anderson [gerente geral da unidade] morreu de rir disso aqui também. Eles achavam engraçado, porque eles estavam vendo que era verdade, eu não estava mentindo. Eu não coloquei mentira nenhuma aqui. (CJ, grifo nosso).
\end{abstract}

Percebe-se uma confiança por parte do empregado naquilo que era retratado no jornal. Para ele, se era verdade, e os demais integrantes da relação eram conscientes disso, não havia problemas de ser exposto desde que não fosse algo tão explícito ao ponto de ferir a relação de respeito entre subordinados e subordinadores imposta pelas regras históricas e sociais de poder.

Nota-se ainda uma predisposição do ator e da plateia em acreditarem conjuntamente nas representações da realidade, talvez por esperarem que as pessoas sempre falem verdades, favorecendo o desenvolvimento da interação, uma vez que dispensa lidar constantemente com situações de desconfiança. 
Em contrapartida, em um outro extremo, está o ator cínico. “Quando um indivíduo não crê em sua própria atuação e não se interessa em última análise pelo que seu público acredita, podemos chamá-lo de cínico." (GOFFMAN, 2013, p. 30). Cabe destacar que nem sempre o ator cínico está interessado somente em enganar sua plateia ou ter algum privilégio pessoal através da representação. Muitas vezes, ele pode iludir seu público pelo o que julga ser para o bem deste, uma maneira de evitar os possíveis conflitos inerentes a toda interação, como os médicos que são levados a receitar medicamentos inócuos para tranquilizar seus pacientes, ou seja, alguns profissionais são exigidos a serem cínicos porque o público não lhes permite serem somente sinceros (GOFFMAN, 2013).

Portanto, o cinismo é uma estratégia interacional para resguardar o ator social de embates arriscados para a manutenção de seu desempenho. Estar atento ao ambiente e às regras de poder ali compartilhadas são orientações importantes para a adoção de um posicionamento cínico premeditado aos interesses da plateia. No contexto das organizações, o cinismo parece ser uma técnica recorrente devido à complexidade das relações construídas nesses locais. As interações ali requerem um cuidado dos envolvidos com suas atuações para não desencadear espetáculos fracassados para plateia e atores. Há muitas questões envolvidas nas organizações interferindo diretamente nos processos comunicacionais construídos em seu âmbito, que vão desde a dinâmica do mundo do trabalho (FÍGARO, 2008) aos enfrentamentos das lutas de classe (ENGELS; MARX, 1999).

Sendo assim, o termo "cinismo", usado por Goffman, pode ser entendido como uma estratégia consciente dos atores na tentativa de satisfazer as expectativas de sua plateia. "Um acordo tácito é mantido entre os atores e a plateia, para agir como se um dado nível de oposição e concordância existisse entre eles.” (GOFFMAN, 2013, p. 256). O comportamento cínico sustenta falsas sensações de harmonia e ordem que contribuem para a manutenção da relação de poder e a garantia da sobrevivência dos empregos dos trabalhadores, por exemplo.

Acredita-se que esta atmosfera de conformidade é utópica, apesar de extremamente desejada pelos diretores, donos, gerentes, etc. No mais, ela seria apenas uma tentativa para manter o status quo hierárquico, um ambiente no qual o ator acredita ser o ideal para sua plateia. "Vemos que os atores, a plateia e os estranhos, todos utilizam técnicas para salvar o espetáculo, quer evitando rupturas possíveis, quer corrigindo as inevitáveis, ou ainda tornando possível que outros o façam.” (GOFFMAN, 2013, p. 257). 
A empresa ao qual o jornal circulou não era diferente. Os empregados pareciam ter consciência dos ajustes que suas atuações deveriam se submeter para adequar ao grupo de gerentes recém contratados e, assim, evitar enfrentamentos explícitos.

Então, de uma forma ou de outra, eu acho que a empresa..., eu não falo do dono da empresa, mas acho que para quem gerenciava, para quem estava no comando, era mais interessante ter sob controle, do que tanta gente tendo opiniões, e sugestões e ponto de vista, muitas vezes nem é o mais interessante para a empresa. (EPB).

O cinismo também pode ser entendido como o resultado da insegurança de um indivíduo. Os atores podem usar essa estratégia para isolar sua personalidade íntima do contato com a plateia (GOFFMAN, 2013), uma maneira de se resguardar da exposição sincera e preservar a impressão que tentam causar nos seus interlocutores.

Essa manobra dramática foi usada pelos empregados incomodados com os conteúdos do jornal. Temendo serem conhecidos como antipáticos, eles resguardavam seus nomes quando iam reclamar da publicação para a gerência. Isso impedia que uma plateia maior tomasse conhecimento do posicionamento particular do ator, assim como relata GM:

\begin{abstract}
A parte de piadinhas, me incomodava muito. E era difícil de medir, era difícil de resolver, porque se eu, por exemplo, falar que não pode. 'Mas quem está reclamando?' Aí eu falo: 'ele reclamou, o fulano reclamou.' Não podia! A pessoa reclamava aquilo em off para a gente. E pedia para não ser revelada porque a empresa era pequena e ficaria antipatizada. (GM, grifo nosso).
\end{abstract}

$\mathrm{Na}$ fala, percebe-se que assim como alguns empregados eram cínicos ao se colocarem contra ao jornal, resguardando esse sentimento do conhecimento da plateia, o gerente também assume ter escondido seu incômodo com as "piadinhas" presentes no informativo. Ambos, empregados insatisfeitos e gerente, se mostram inseguros em serem sinceros nas representações, adotando o cinismo como uma estratégia para evitar transtornos com a plateia.

\title{
Considerações
}

Embasando-se nos conceitos de ator sincero e ator cínico, nota-se que o indivíduo não está preso em apenas um dos extremos da representação. Ele oscila situacionalmente entre a sinceridade e o cinismo.

Através das entrevistas infere-se que os empregados são conscientes de que seu cinismo é reconhecido por sua plateia, mas, como já apresentado, ao ator cínico pouco 
importa o que seu público acredita, e pode até experimentar uma "jubilosa agressão espiritual" pelo fato de brincar com algo que a plateia aparentemente está levando a sério (GOFFMAN, 2013). Enfim, esses fatores apenas reforçam a ideia de que existe um acordo invisível e em certa medida satisfatório entre as duas partes. O empregado finge que está em conformidade ao discurso de seus superiores e os superiores aparentam acreditar nele. Portanto, o cinismo pode ser uma estratégia tanto dos subordinados como dos subordinadores.

Para aprofundar ainda mais a discussão, sugere-se novas investidas que articulem as estratégias de interação com a análise do discurso dos atores envolvidos na situação. Parte-se do pressuposto que os atores sociais marcam suas estratégias de comunicação também por meio dos discursos construídos e praticados.

No caso deste estudo, nota-se como um veículo de comunicação, criado espontaneamente em um ambiente organizacional, consegue alterar sistematicamente a relação entre subordinados e subordinadores, atualizando as estratégias utilizadas por eles e exigindo novas formas de representação dos papéis sociais de acordo com a situação de interação.

Portanto, considera-se as organizações como espaços onde a vida cotidiana também é praticada e, portanto, local de trocas simbólicas marcadas pela dramatização dos atores, trazendo à tona a astúcia daqueles geralmente subjugados como apenas reprodutores do discurso oficial das empresas, os empregados.

\section{Referências}

ALMEIDA, Roberto; LIMA, Fábia. Interação. In: Enciclopédia Intercom de Comunicação. São Paulo: Sociedade Brasileira de Estudos Interdisciplinares da Comunicação, v. 1, 2010, p. 705-706.

BALDISSERA, Rudimar. Comunicação Organizacional na perspectiva da complexidade. Organicom (USP), v. 10-11, p. 115-120, 2009.

D’ALMEIDA, Nicole. O estatuto do Sujeito em Organização. In: MARQUES, Angela Cristina Salgueiro; OLIVEIRA, Ivone de Lourdes (org). Comunicação Organizacional: dimensões epistemológicas e discursivas. Belo Horizonte : Faculdade de Filosofia e Ciências Humanas. 2015. p. 18-26. 
DALTOE, Andrelise. Promessas, Desafios e Ameaças das Tecnologias Digitais. Thésis Revista dos alunos da Pós-Graduação Stricto Sensu da Faculdade Cásper Libero, São Paulo, p. 52 - 62, 02 mar. 2004.

FAUSTO NETO, Antonio. Como as linguagens afetam e são afetadas na circulação?. In: Antônio Fausto Neto; José Luiz Braga; Jairo Ferreira; Pedro Gilberto Gomes. (Org.). Dez perguntas para a produção de conhecimento em comunicação. 1ed.São Leopoldo: Unisinos, 2013, v. 1, p. 43-64.

ENGELS, F; MARX, K.. Manifesto do Partido Comunista. 9. ed. Petrópolis, RJ: Vozes, 1999.

FERIN, Isabel. A comunicação e os estudos disciplinares contemporâneos. In: Comunicação e culturas do quotidiano. Lisboa: Quimera, 2002, p. 49-98.

FÍGARO, Roseli. Relações de Comunicação no mundo do trabalho. 1. ed. São Paulo: Anna Blume, 2008. v. I. 160p.

FRANÇA, Vera Veiga. Contribuições de G.H. Mead para pensar a comunicação. In: 16 Encontro Anual da COMPOS, 2007, Curitiba. Anais do 16 Encontro da COMPOS - GT Epistemologia da Comunicação. Curitiba: COMPOS - UTP (Universidade Tuiuti do Paraná), 2007. v. 1.p. 1-16.

FRANÇA, Vera Veiga. Interações comunicativas: a matriz conceitual de G. H. Mead. In: PRIMO, Alex; OLIVEIRA, A.C.; NASCIMENTO, G.; RONSINI, V.M.. (Org.). Comunicação e Interações. 1ed.Porto Alegre: Sulina, 2008, v. 1, p. 71-91.

FRANÇA, Vera Veiga; SIMÕES, Paula Guimarães. Interação. In: FRANÇA, Vera; MARTINS, Bruno; MENDES, André. (Org.). Grupo de Pesquisa em Imagem e Sociabilidade (GRIS): trajetória, conceitos e pesquisa em comunicação. 1ed.Belo Horizonte: PPGCOM UFMG, 2014, v., p. 99-102.

GOFFMAN, Erving Ritual de interação: ensaios sobre o comportamento face a face. Petrópolis, RJ: Vozes, 2011, 258 p.

GOFFMAN, Erving. A representação do eu na vida cotidiana. 19 ed. Petrópolis, RJ: Vozes, 2013, 273 p.

LIMA, Fábia P.. Possíveis contribuições do paradigma relacional para o estudo da comunicação no contexto organizacional. In: OLIVEIRA, Ivone de L.; SOARES, Ana Thereza N. (orgs). Interfaces e Tendências da Comunicação no Contexto das Organizações. São Caetano do Sul, SP: Difusão Editora, 2008, p. 109-127.

OLIVEIRA, Ivone de Lourdes; PAULA, Carine Fonseca Caetano. Comunicação organizacional e relações públicas: caminhos que se cruzam, entrecruzam ou sobrepõem? In: CONGRESSO BRASILEIRO DE CIÊNCIAS DA COMUNICAÇÃ̃O, 28., 2005, Rio de Janeiro. Anais... Rio de Janeiro: INTERCOM, 2005. 1 CD-ROM. 
PIÃONEIRO. Lagoa da Prata - MG. Mar/2006.

RODA LIVRE. Lagoa da Prata - MG. Abr/2006a.

RODA LIVRE. Lagoa da Prata - MG. Mai/2006b.

RODA LIVRE. Lagoa da Prata - MG. Jun/2006c.

RODA LIVRE. Lagoa da Prata - MG. Ago/2006d.

RODA LIVRE. Lagoa da Prata - MG. Set/2006e.

RODA LIVRE. Lagoa da Prata - MG. Out/2006f.

RODA LIVRE. Lagoa da Prata - MG. Nov/2006g.

SERRA, J. Paulo. Manual da Teoria da Comunicação. Covilhã: Universidade da Beira Interior, 2007.

WOOD JR, T. Organizações Espetaculares. Rio de Janeiro: Editora FGV, 2001. 206 p. 